\title{
Stress management in South Africa
}

\author{
D.J.W. Strümpfer \\ Department of Psychology, University of Cape Town, Cape Town
}

\begin{abstract}
A distinction is made between eustress and distress, and the complexity of stress phenomena is emphasized. Acceptance of corporate social responsibility is posed as the most fundamental form of stress management at the social and community level. Sound management practices are viewed as basic to health-enhancing organizations. Occupational differences are highlighted. Stress management training is discussed in terms of who needs training, individual vs. group approaches, and objectives. Knowledge acquisition and self-assessment are introduced. Brief discussions of specific skills training follow: Relaxation, physical exercise, rational-emotive thinking, goal setting, time management, personal and career development counselling, and preventive health management. Lastly, employee counselling programmes are mentioned. The role of follow-up evaluation is emphasized.

S. Afr. J. Bus. Mgmt. 1985, 16: $61-70$
\end{abstract}

Onderskeid word getref tussen 'goeie' en 'slegte' spanning en die kompleksiteit van spanningverskynsels word beklem. toon. Aanvaarding van korporatiewe sosiale verantwoordelikheid word geopper as die mees fundamentele vorm van spanninghantering op sosiale en gemeenskapsvlak. Gesonde bestuurspraktyke word beskou as grondliggend aan gesondheid-bevorderende-organisasies. Beroepsverskille word toegelig. Opleiding in die hantering van spanning word bespreek in terme van wie dit benodig, individuele vs. groepsbenaderings, en oogmerke. Verkryging van kennis en selfevaluering word genoem. Kort besprekings van opleiding in bepaalde vaardighede volg: Ontspanning, liggaamsoefening, rasioneel-emotiewe denke, doelwitstelling, tydsbenutting, voorligting by persoonlike en loopbaanontwikkeling en voorkomende gesondheidsorg. Laastens, word werknemervoorligtingprogramme vermeld. Die rol van opvolgevaluasie word beklemtoon.

S.Afr. Tydskr. Bedryfsl. 1985, 16: $61-70$

Expanded version of paper presented at the 28th Convention of Institute of Personnel Management (Southem Africa), Sun City, Boputhatswana, 3 October 1984.

D.J.W. Strümpfer

Department of Psychology, University of Cape Town, Private Bag, Rondebosch, 7700 Republic of South Africa

Accepted February 1985
That the birds of worry and care fly above your head, this you cannot change. But that they build nests in your hair, this you can prevent.

- Chinese proverb.

\section{Introduction}

Much of what is said and written about stress is based on dubious assumptions. We are often viewed as passive victims who have minimal ability to cope. We are assumed not to be able to take advantage of the opportunities presented by late 20th century technology, industry and business, but are supposedly under constant threat from their dangerous sideeffects. The consequences of assumptions like these are a helpless, hopeless attitude of stress avoidance and a cynical tendency to reject all deep involvement, striving, and enthusiasm as if these somehow represent decadence.

Assumptions to the contrary can also be made, namely that the vast majority of people have an inherent motive to be competent in their interactions with the world around them; that they have the potential to develop a general orientation that views life as meaningful, predictable and manageable; as well as that they have the potential to develop as hardy personalities who can interact with their environment with a sense of commitment, a belief in personal control, and an expectation of challenge (see Strümpfer, 1983b). Social class advantages and privileged occupational experiences contribute to the actualization of these potentialities, but the potential need not be denied; and creation of optimal conditions is by no means contrary to organizational and social objectives.

When people face life with competence and hardiness, much of stress should rather be described as 'eustress' (Greek eu- = good; Klausner, 1968): A positive, pleasant, facilitating responding to demands. Such 'working with joy' is physically healthy, psychologically invigorating and careerenhancing, as well as highly beneficial to one's employing organization.

On the other hand, it is possible to carry on too long and to wear oneself out to the point of dangerous exhaustion and distress (or 'bad' stress). There are also overwhelming, uncontrollable circumstances which can drag individuals, groups and whole communities down into distress that can destroy physical, psychological, and social health. It is this kind of distress that is often equated to 'stress', an unfortunate usage I shall try to avoid in this article. Prevention of such exhaustion, as well as alleviation, amelioration and treatment when it has occurred at the personal or group level, are the objectives of distress management programmes. In part, it is a matter of personal responsibility but often the person 
needs support and assistance from professionals; hence the interest of personnel management in this topic.

However, it is not only individuals who seek eustress and try to avoid distress. Whole organizations could have related aims: To create optimal conditions of eustress for individual members and groups, and to minimize conditions for distress. In part, the goal would be favourable conditions for productivity and improved performance. Naturally, some distress is inevitable in any job and every working person is bound to experience such unpleasantness sooner or later; but a 'health enhancing organization will attempt to ensure that jobs are not typically consistently overloaded with potential stressors' (Simpson, 1983). The other side of the coin is for the organization to shoulder social responsibility, to demonstrate that, in addition to being concerned with the physical and psychological wellness of employees as individuals and groups, it also has a deep concern for the welfare of society and of the community.

\section{Stress - a very complex matter}

The experience of stress, whether bad or good, and everything related to stress, is - like all human functioning - a matter of a large number and variety of components in dynamic interaction. The main reason why the literature on stress and teachings about stress management are so confusing, is our tendency to oversimplify by attending to a single component in isolation, or at most to a small number of components. Stress phenomena can be neither understood nor controlled in three, or five, or ten easy steps. We are often like the blind men in the Indian legend who each defined an elephant in terms of only that part of the elephant he had had opportunity to explore. Trouble could, however, start when we try to become elephant handlers on the basis of such limited under. standing of a rather massive animal.

At the same time, let us not be too harsh on some would-be elephant handlers. It is hard for a consultant (internal or external) to sell an unpackageable, unprogrammable structure of concepts that requires constant revision and adaptation for each client and each situation. There is an understandable need to single out manageable components. But a piecemeal approach should be labelled as such and should not be presented as if it is the last word or greatest development on stress management. On the contrary, problems of this magnitude demand scientific and professional humility that will encourage us to continue the search for understanding and for more and better ways of dealing with them.

Figure 1 presents a model that indicates classes of-components of organizational stress (see labelled rectangles), with examples listed under each heading. It also indicates interactions between components, with solid arrows indicating direct

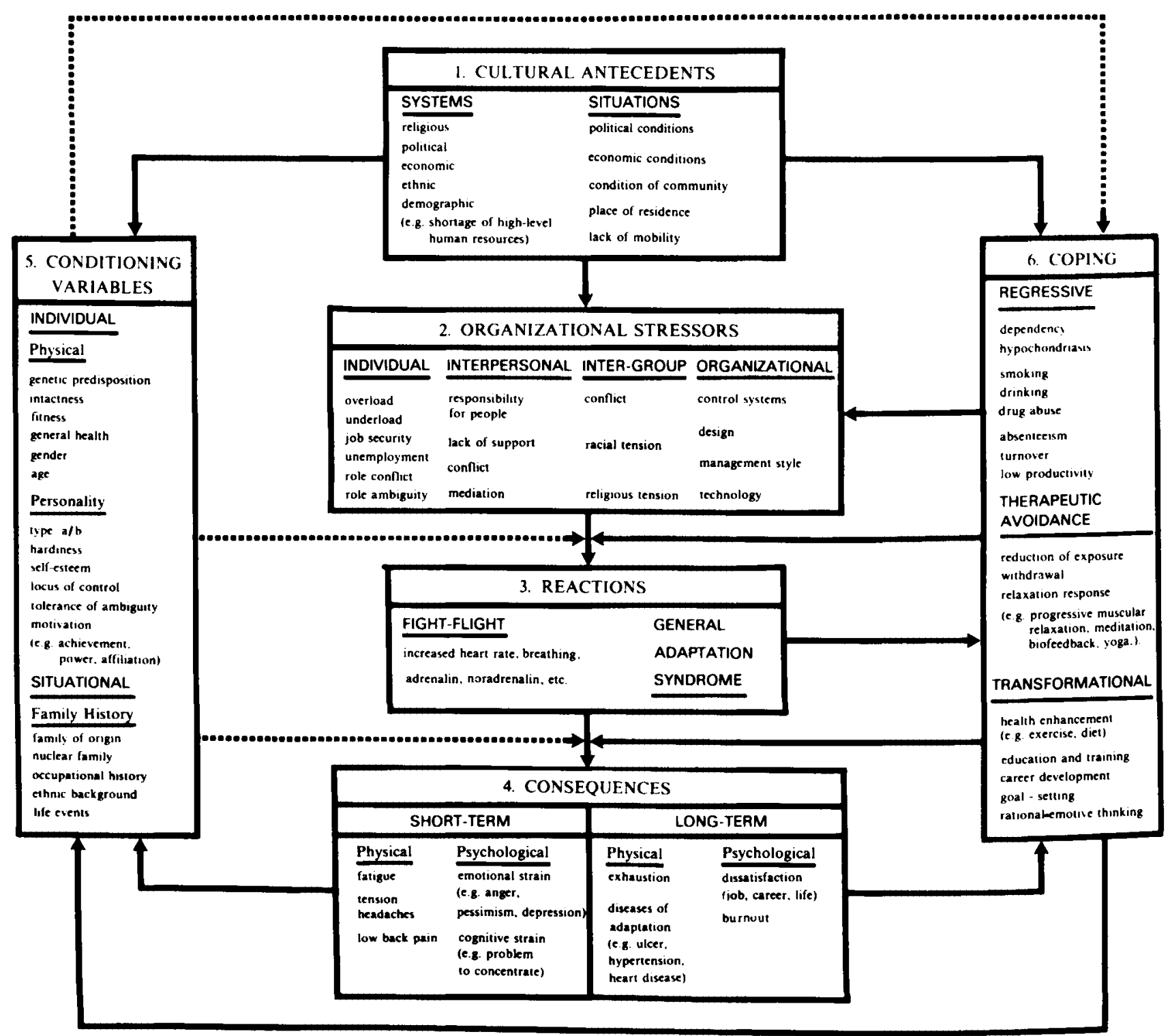

Figure 1 Components of organizational stress and their interactions. 
influences of one component leading to another, and brokenline arrows indicating processes which condition, i.e. strengthen or weaken, interactions. I have discussed the detail of this model elsewhere (Strümpfer, 1983b; 1983c) and intend to use the model here only as a frame of reference and as a reminder to maintain as broad a view of organizational stress as possible.

\section{Corporate social responsibility and stress}

When one begins to think of how to enhance eustress and how to decrease distress, it is foolish, if not downright dangerous, to start thinking of individuals in the first place. One has to start with the whole of a society and with the communities within it, approaching the matter in a holistic or general systems way.

The first rectangle in Figure 1 refers to 'cultural antecedents' of stress, in the sense that the total environment forms the backdrop to everything an individual experiences. The relative 'health' of a society, in terms of social, political, economic and educational conditions, will contribute to the balance of eustress - distress experienced by its members.

In terms of a community, one could use the concept of solidarity, an attitude of responsibility towards one another, a feeling of confidence and optimism towards tasks to be accomplished, and the ability of its social systems to satisfy the needs of members (Strümpfer, 1975). A lack of solidarity results from factors such as poor or limited leadership, high incidence of poorly integrated or broken families, poverty in general, poor housing, few recreational activities and facilities, high incidence of juvenile and adult delinquency, as well as poor and disrupted networks of communication and interpersonal support. High levels of aggression and hostility within the community and against outsiders are characteristics of a community that lacks solidarity. Obviously, solidarity contributes immensely to the eustress orientation, while lack of solidarity is a fertile condition for distress. Unfortunately there is no way of denying that the world of industrial workers, particularly that of blacks, typically shows no or very few of the positive characteristics of solidarity which people higher up the organizational ladder consider as their birthright.

Corporate social responsibility demands that companies consider broader social issues and allocate resources for broader social purposes. I should like to quote from Bloom's (1984) talk to the U.S. Business Council earlier:

'this approach is plainly correct because active involvement can be justified on the basis that it is patently obvious that it is in our interests to operate in a stable and healthy society, a society which is not jeopardised by the deterioration of conditons in its environment. Let us be clear there can be no profits for business and no future for people in a disintegrating community, a community characterised by unemployment, civil disorder or crime, anywhere in the world.'

Social policy codes usually express intentions and commitments in this connection, apart from those concerning employment practices. Companies can make significant contributions towards the quality of workers' lives outside the work environment, for instance through housing subsidies, bursaries and other educational assistance, literacy and numeracy training, medical aid funding and legal counselling. They can also support charitable and philantropic projects that can benefit whole communities.

Bloom (1984) also made a point of political involvement, that companies should speak out on matters of national importance, such as removals, detentions and bannings. With the racial and political conditions in South Africa in 'violent equilibrium' (The riots, 1984) and with the vast majority of their employees often being of the unprivileged class, companies cannot afford attempts at political neutrality not for political reasons in the first place, but for the sake of the total wellness of their work-force.

In the case of lower level employees, such indirect contributions may be more worthwhile than any direct attempts at stress management. If a choice has to be made, general quality of life for such an individual, his/her family, friends and community, are far more fundamental, embracing, and lasting than many of the things which, for instance, executives who take a good life outside work for granted, may consider a sign of special caring by the company. And if contributions to communal good are what a company chooses, in preference to stress management training, it will still be on the side of the angels!

Activities of this kind are not immediately visible and substantial because they are long-term investments. Intervention at this level is therefore much harder to sell to top management (or to shareholders) than e.g. a particular training or counselling programme. It takes a far-sighted and courageous management to become involved at this level. Yet it is the most fundamental form of 'stress management', and absolutely essential in South Africa.

\section{Sound management practices}

When one looks at any list of organizational stressors (e.g. in Figure 1), it is quite obvious that many of them ought not to be dealt with in a symptomatic way. Organizational stressors result from unsound people-management practices and the remedy should be sought in improving the psychological and social health of the organization as a whole. Authors like Argyris, Bennis, Likert, McGregor and Schein have described healthy, as opposed to unhealthy organizations. To list but a few characteristics from Fordyce \& Weil's (1979: 13-16) list of indications of organizational health:

- There is a noticeable sense of team playing in planning, in performance and discipline - in short, a sharing of responsibility.

- The judgement of people lower down in the organization is respected.

- The range of problems tackled includes personal needs and human relationships.

- Collaboration is freely entered into.

- Conflicts are considered important to decision-making and personal growth.

- Leadership is flexible, shifting in style and person to suit the situation.

- Poor performance is confronted, and a joint resolution sought.

- Managers' orientation is to 'work the problem', not to 'find the culprit'.

An organization characterized by behaviour of this kind will be much more conducive to individual eustress than to distress, and distress will be much more readily managed in such an environment than in one fraught with authoritarianism, rejection, mistrust, prejudice, hostility, exploitation and the like.

A study at the University of Michigan (Caplan, Cobb, French, Van Harrison \& Pinneau, 1975) compared distressors among 23 different occupations. The major distressors for professional and white-collar workers resulted from factors like too little delegation and too little decentralization of tasks and decision-making. For blue-collar workers, the major 
stressors tended to go in the opposite direction, e.g. lack of job complexity and under-utilization of abilities. Cooper's conclusion from this study was:

'This may indicate the reason why there is a growing movement in Western Europe and North America for greater industrial democracy at work (e.g. autonomous work groups, group decision-making, job re-design etc.). It may be that greater movement in the direction of delegating decision-making downward in a wide variety of jobs would not only alleviate stress among white-collar and professional workers but also encourage greater utilization of abilities and enhance job satisfaction among blue-collar workers.' (Cooper, 1980: 50)

For reasons such as these, I want to pose organizational development, development of sound personnel practices (including the design and re-design of work), and sound industrial relations as the most fundamental ways of managing stress within any organization. An organization that is wellrun in its totality will create eustress in its members and groups, and will in the natural way of things eliminate many distressful conditions.

Part of the orientation described above would be a reevaluation of the human resources of a firm, not only in humanistic terms but also in financial terms, as a capital asset. Unlike the case with machines and other equipment, the wear and tear on people by work, and the need for maintenance are too often simply ignored. Re-evaluation implies an acceptance of the reality of distress in organizational life (Cooper, 1984). This, in turn, would prepare the organization so that specific stress management interventions will seem like the logical next step. On the other hand, a stress management training programme installed into an organization that malignantly generates distress through unsound management will be rejected like a foreign body or a transplant from a stranger.

\section{Occupational differences}

The concept of 'stress' is often popularly associated with higher levels of management, as if it is 'the boss' disease' or 'the directors' disease'. Of course, people experience distress of various kinds at all levels of employment and in a wide variety of occupations. 'Work pressure affects all workers and ... the sources and manifestations of stress vary from occupation to occupation' (Cooper, 1980: 49).

At the lower organizational levels 'blue-collar stress' is often related to the more physical conditions of work, to boredom, ambiguity about job future, and other relatively concrete factors (Caplan et al., 1975; Poulton, 1978; Shostak, 1980). 'Subordinate service role' distress (Shamir, 1980) is quite a different kind of lower level distress, experienced by people in positions at the interface between an organization and its clientele, for instance waiters, sales clerks, receptionists, and bank tellers. At supervisory and managerial levels distress is characterized by a variety of psychological factors that are not present in either of these kinds of work (Strümpfer, 1983b). In managerial and supervisory ranks, moreover, job level seems to be inversely related to distress, as well as to general health (Howard, 1976).

Other occupational groups are, of course, also subject to distress. Air traffic controllers have almost become part of the stress folklore, as a result of their tension - filled and overloaded work lives (Crump, Cooper \& Maxwell, 1981; Henry, 1981). As the term was used initially, 'burnout' was a consequence of distress among human service professionals, like social workers, psychologists, psychiatrists, nurses, policemen and prison personnel (Maslach \& Jackson, 1982); here the deep emotional involvement with people seems to be the most prominent feature. Other occupational groups could also be mentioned (Cooper \& Marshall, 1980).

What is important, is to keep an open mind to the diversity of stressors and distress experiences that result from various kinds of occupation. Even when some of the reactions and consequences (Figure 1) seem similar, the context of the total experience and the ways available to prevent and/or ameliorate it, demand attention to this diversity. No single intervention is likely to work for all occupational groups. Up to a point, stress management programmes, therefore, have to be occupation-specific.

\section{Individual-orientated stress management training}

\section{Who needs stress management training?}

Participation in any stress management activity should always be voluntary. Since personal stress management is always, in the final instance, a matter of self-management, the motivation for participation should be that of the participant. Subordinates cannot be assigned to such a programme, and even a mild or subtle suggestion that a person needs it, should be avoided. If employee attendance is in any way required by the company, the facilitator can just as well give up. Participants have to accept the premise that stress may be important in their lives, particularly at work. Hence the only way to present a programme with any hope of success is 'to let people know what the program is all about (the objective); why they may want to attend (the rationale); and what they might expect to gain; and then let the individual decide' (Matteson \& Ivancevich, 1982b:711).

Individual differences (Rectangles 5 and 6 in Figure 1) will affect such decisions. Even though no one can deny the omnipresence of stressors, and even though a psychologist may be convinced that everyone exposed to a particular job situation must experience it as distressful, there will probably always be some hardy individuals who find that situation 'normal', even invigorating and exhilarating (Strümpfer, 1983b). At the same time, there are achievement-motivated people who are constantly seeking the advice and aid of experts who can help them to improve their performance and who may welcome some stress management techniques for pro-active purposes. For such reasons, all people who, on the basis of what has been presented to them, feel that the programme might be helpful should have access to it.

When an organization begins considering introduction of stress management, a frequent question is where to start. Many top-flight companies have chosen to involve managerial and supervisory personnel first. More socialistically inclined commentators find fault with such a priority, on the grounds that since the physical, psychological and social conditions of work at lower levels are much less favourable, ordinary workers should get alleviation first. Of course, this is a complicated matter, particularly since the kinds of distress differ at different levels, and hence the remedy required.

Matteson \& Ivancevich (1982b) expressed the opinion that, all else being equal, supervisory and management personnel should be selected first. Their reasons were, first, that they carry significant responsibility for people, a stressor that research has consistently shown to be worse than responsibility for things; and, second, that if superiors understand distress better, they will be in a better position to help employees identify and deal with distress. Simpson (1983) added another cogent reason: "executives have a greater impact on the economic well being of an organisation and hence, any incompetence 
as a result of stress at an executive level will probably have more significant results on the organisation's bottom line'.

Next, Matteson and Ivancevich advised that one should identify groups of employees in high-distress jobs, for instance those with:

'unusually prolonged deadline pressures; chronic work overload; constant change in requirements, procedures, schedules or even supervisors; frequent physical danger; minimum opportunities to interact with others and thus build social-support networks; or highly automated and repetitive tasks.' (Matteson \& Ivancevich, 1982b: 771)

Thirdly, these authors referred to groups of employees who are particularly susceptible to distress, regardless of their actual work, for instance, very young and inexperienced employees, older employees on a career plateau but still making a worthwhile contribution, recently transferred people, and 'minority' group members (as an example, they mentioned 'in some cases, females'; black managers would also be a good example in this country).

Lastly, personnel and productivity criteria, like abnormal levels of turnover and absenteeism, accidents, escalating costs or production decrements, may flag distress in work groups, if these cannot be explained in terms of causes not related to distress.

\section{Individual vs. group programmes}

The causes of distress may be so specific to an individual that an individual stress management programme, of the nature of personal counselling, may be required. For instance, in the case of senior managers, psychological problems can hardly be dealt with in a group setting. Another example may be distress related to career-development, where at least a large portion of the counselling process has to be individualized. Problems around the mid-career transition are also likely to require individual attention. Similarly, exercise programmes for people who are at risk for coronary heart diseases have to be individualized, at least for an initial period.

In view of the relative infrequency of such situations, of the specialized training and skills required, of confidentiality, as well as the costliness of individual problem management, it may make sense to use outside consultants for such approaches. Very large organizations may, however, have work enough of this kind to employ counselling or clinical psychologists, physicians, and biokineticists. At the same time, not just any member of these occupations will be useful. Apart from high-level professional training, it takes an orientation towards health, rather than pathology (therefore, e.g., counselling rather than clinical psychology), as well as a certain amount of industrial/organizational experience and insight a combination hard to gather.

Group-based programmes have various advantages. The most obvious is cost-effectiveness. The second is that the same kind of problems occur frequently enough that people experiencing them can be brought together. The third is that people with similar problems can help, support and reinforce each other's behaviour in the right kind of group setting. Lastly, motivation for compliance tends to run higher in group approaches.

In organizations status differences cannot be ignored and the constitution of groups may require careful consideration from this point of view. Superiors and subordinates should almost never be in the same group. Groups of peers are likely to work better than groups with wide differences in rank represented. People who have to work together daily may also require careful forethought (husband-wife combinations should probably be ruled out altogether). If the training objectives are more psychological in nature, diversity among group members may, however, be a very valuable characteristic to build into the group.

The exceptional situation where a natural work group should work together is in dealing with 'role stress' problems. Role conflict and role ambiguity, as well as role overload, have frequently been identified as distressors. Behavioural consultants have developed a variety of role clarification procedures to generate a discussion of roles and to clarify the expectations of members. One example is the role analysis technique (Dayal \& Thomas, 1968; French \& Bell, 1978; Lynton, 1968).

Some knowledge of group dynamics, as well as skill and experience of running relatively instructured group training, are obvious qualifications of a trainer, preferably to be obtained under supervision.

\section{Goals and Objectives}

Before considering content, any trainer would want to set goals and objectives. In terms of fairly global goals, distress management programmes may be directed at remediation, prevention or enhancement of wellness, or at all three. On another continuum, they may range from a broad approach of teaching information and skills that would be useful in many life situations, to being directed at specific work conditions. A programme may also range from being basically informative and theory-based, to being orientated towards teaching one or more skills. In determining the goals of one's programme, the needs of the organization and of the target groups, as well as the availability of resources, like skilled staff, financing, and participant time, have to be considered.

In terms of fairly concrete objectives, Matteson and Ivancevich suggested firstly, knowledge acquisition: 'Any program should present information that will be useful to the participants, in increasing their awareness of stress, its role in their lives, and how it works for and against them' (Matteson \& Ivancevich, 1982b: 771). As an example, they mentioned awareness and understanding of the physiological and biochemical changes that take place in one's body under distress: Knowledge of these changes and their relationship to negative health factors would make one much more stress conscious. Knowledge of behavioural manifestations of distress is another example: T eaching an early warning system to help one recognize the onset of a problem and diagnose it properly, whether in oneself, one's colleagues or one's subordinates (see also Cooper, 1984).

Matteson \& Ivancevich considered skill acquisition as the second objective, providing specific, 'usable skills that can be applied in a variety of circumstances both on and off the job' (p. 772) to prevent a distress reaction or to dissipate the effects of distress more productively; or to formulate it even more generally, to teach participants greater control over physiological and psychological systems which are reactive to distress (Murphy, 1984). The programme should provide for both demonstration and adequate practice during training, as well as provide ways of preparing for 'back-home' applications.

Their third objective was feedback: 'providing participants with specific information about their current levels of stress and certain of their behavior patterns and personal orientations that can serve as a basis for more effective stress management' (p. 772). 


\section{General knowledge and self-knowledge}

\section{Knowledge acquisition}

It has become customary in management and other concentrated training programmes to require pre-course reading. Provided the volume and quality of reading are not in themselves causes of distress, I see no reason why stress management workshops for higher level employees cannot start this way. Obviously, the reading material should be adapted to the reading level of participants. Many readable articles could serve this purpose, while books like those of Greenberg (1983), Ivancevich \& Matteson (1980), Matteson \& Ivancevich (1982a), Moss (1981) and Shaffer (1982) may be useful. Reading assignments can also be given during and after a workshop.

Although lecturing is a poor way of conveying information, lectures and lecturettes have their place during a workshop. Films are absorbing and interesting ways of conveying information (some examples are listed in Appendix 1).

Ideally, theory inputs should cover all of the areas indicated in Figure 1, but practical circumstances will determine the extent of coverage. Participants should be involved through small group discussion and interaction, perhaps in reaction to a lecture, a film, or a specific question. Descriptions of personal critical incidences, experiential exercises, role plays and case studies could all increase participation.

\section{Self assessment}

Following theory inputs (perhaps even as part of pre-work), participants should have opportunities to assess themselves with respect to the information provided. According to Matteson \& Ivancevich (1982b: 773), self-assessment 'heightens involvement, provides a data base upon which participants can further their understanding of how stress relates to them, and generally reinforces both learning and transfer'. Matteson \& Ivancevich also cautioned that participants should always be assured of the confidentiality of such data and that they should feel no direct or indirect pressure to share them with anyone.

Some of the books listed in the previous section contain examples of questionnaires that could be used for such purposes. Caplan, et al. (1975) provided scales that could be useful to describe many job distressors. The Crown-Crisp Experiential Index (Crown \& Crisp, 1979) is a somewhat clinical instrument but three of its scales were used in Cooper \& Arbose's (1984) executive stress survey for International Management, thus providing for some stimulating crosscultural inputs as part of a workshop. Cooper and Arbose also used a list of pressures, commonly experienced by executives, which could similarly be used to compare South Africans with their South African sample and samples from nine other countries. The Jenkins Activity Survey (Jenkins, Zyzanski \& Rosenman, 1979) is a handy measure of Type A behaviour; a 13-item short form may be useful in some situations (Jenkins, 1984). (An Afrikaans translation is available from me, but a fee is payable to the Psychological Corporation, and I also have data on a variety of South African samples (Strümpfer, 1983a)). Of course, a variety of other instruments deserve serious consideration. Instruments should preferably 'be short, easy to understand, ideally fun to complete (at least not a chore), and possess a good degree of face validity' (Matteson \& Ivancevich, 1982b: 373).

A serious limitation in connection with all self-assessment measures (apart from reliability and validity, which cannot necessarily be assumed for scales provided in several books) is that of standardization, particularly for South African samples. (There is room for several masters and doctoral dissertations in this area alone!)

An aspect that should be remembered is that most of the available stress measures are subject to copyright and as a matter of professional ethics, as well as a matter of protection against prosecution, users should buy them through the National Institute of Personnel Research or obtain permission for duplication from authors or publishers.

\section{Skills training}

The range of stress-related skills is too wide to be covered adequately in an article like this one. Voluminous tomes, like the 499-page one edited by Meichenbaum \& Jaremko (1982), and piles of articles unfortunately have to be waded through if one wants to develop an adequate background. A review article by Murphy (1984) can provide useful references. I intend to introduce what I (please note the limitation) consider among the most important skills, with some comments, but also with reading references that will hopefully provide leads for people interested in additional information. In general, all of these skills should generalize from the training situation to the person's whole way of life, rather than to be of temporary remedial or therapeutic significance only.

\section{Relaxation techniques}

Relaxation in some form or another is probably the most commonly used distress management technique and has been shown to be effective in various groups (Carrington, Collings, Benson, Robinson, Wood, Lehrer, Woolfolk \& Cole, 1980). Progressive muscular relaxation was introduced long before there even was the concept of stress to be managed. Its popularity probably stems from its obvious face validity, its ease of use, and its almost immediate benefits. As it is used nowadays, the person usually starts off with a relatively long form, requiring $20-25 \mathrm{~min}$. at a time for two-four weeks of regular practice; some 16 to 20 relatively small groups of muscles, like a foot, then a calf, then an upper leg, etc., are tensed and relaxed alternatively, working up from the feet to the face. For the next two - three weeks' practice, body parts are combined, e.g. a foot, calf and upper leg all together, reducing the number of muscle groups to seven. Then follows a week or two where the number of muscle groups is reduced to only four. This is followed by a stage of recall only, where the individual recalls the feeling of relcase in situations which tend to cause tension. By this time the person is usually capable of locating areas of tension, then relaxing them by simply giving him/herself a command, like 'Relax, calm down', taking a deep, slow breath and focusing on the muscle groups concerned. It is often combined with cue-control, using sticky coloured dots (or stars) to paste on places and things at work and at home which (s)he frequently experiences as tension-inducing; each encounter with a coloured dot then serves as a cue to the relaxation response. Although these instructions are quite simple, some psychological skill may be necessary in handling some clients.

Meditation is another way of evoking what Benson (1974; Benson \& Allen, 1980) has called the 'relaxation response'. He introduced the 'respiratory one method', a non-cultic technique in which mental repetition of the word 'one' is linked with each outbreath, for a period of 10-20 min. (see Peters \& Benson, 1978: 124 for instructions). Transcendental meditation is the more familiar method but there are research indications that the relaxation response at the core of the technique can also be taught in an unembellished form.

Biofeedback training can be used to induce generalized 
relaxation but it is probably more appropriate for use in behavioural medicine, e.g. for the treatment of tension headaches and migraine. Its main disadvantages are that, unlike progressive muscular relaxation, it is 'non-portable' (Roskies \& Avard, 1982), and requires special equipment and special trainer training. Both equipment and operators are expensive. Miniaturized units are less expensive but not necessarily reliable and are still more cumbersome than no equipment at all.

Impressed with the therapeutic successes of relaxation with acute distress, hypertension and other conditions, some authors and consultants have suggested that a relaxation technique should become part of every person's daily armamentarium against distress. In South Africa there is an unusual preponderance of Type A behaviour among executives, as well as a very serious shortage of high-level human resources which call for a Type A kind of life-style to survive and succeed (Strümpfer, 1983a). At least for such go-getters, it is unrealistic to hope for continued regular practice of a relaxation-inducing technique. It is too passive an approach and is readily rejected as incompatible with 'real life'. Hence, my suggestion is that progressive muscular relaxation taught as described above, should be used initially as a therapeutic technique but afterwards it can become a skill available to the individual, to be used only when necessary. Of course, some reinforcement practice will be necessary from time to time. Perhaps I should add that for people who can continue with e.g. meditation because it fits their temperament, it may prove to be a very valuable component of a different lifestyle. My only concern is not to reach for the unattainable in one's enthusiasm for something which only a small proportion of one's clients are likely to accept fully.

\section{Physical fitness programmes}

While relaxation skills can help an individual to handle a particular tension-provoking experience, regular physical exercise will have a more general preventative and health-enhancing aspect. It is the most natural way of releasing the pent-up arousal that results from distress; but by increasing fitness and by contributing to healthier emotional functioning it can help the individual to work with more vigour and equanimity, thus also contributing to eustress.

The so-called 'fight-flight mechanism' is the body's response to threat and consists of a mustering of all resources in preparation for the strenuous activity required by an emergency. Under relatively primitive conditions such arousal is dissipated by fight or flight but civilization has removed the predominantly physical orientation from our lives. In numerous present-day work situations threats, ranging from the brutal to the subtle, arouse the fight-flight mechanism; but neither fight nor flight is an appropriate response to such distress in the office or factory. Consequently, there is hardly any relief from the intense physiological arousal that is part of our daily routine. This 'unnatural' situation then calls for introduction of artificial exercise as an outlet and to prevent a harmful build-up of consequences of distress (see Figure 1).

The nature of exercise is a matter of personal taste, needs and opportunities. Fitness programmes need not be limited to the perquisite of an executive gymnasium but could be made available in various forms to all employees. In fact, in combination with contributions to recreation facilities, this is an area where companies can do a great deal for lower level employees and even for the communities in which they live.

It is also interesting that the active approach of handling distress by means of exercise holds so much appeal for the
South African go-getters I mentioned above. It is not yet as overwhelming as the American scene where, 'At times it seemed as if Judaeo-Christian civilization had been overrun by pagan-aerobic tribes' (Sheppard, 1981); but the popularity of various forms of exercise among executives and workers, whites and blacks augurs well for distress management and the general enhancement of health.

Since few personnel managers have training in exercise science and in view of some coronary and other medical risks, a well-trained biokineticist should be involved whenever physical exercise is introduced as part of a stress management programme. Obviously, it cannot be more than talked about in a workshop kind of programme.

\section{Rationalemotive thinking}

Feelings and the way people think should also be brought into the process of distress-eustress management. Training in rational-emotive thinking provides one vehicle for doing so. Ethel Roskies (1983; Roskies \& Avard, 1982) adapted Albert Ellis' rational-emotive individual psychotherapy to a group technique of helping people to adjust, or modulate, negative emotions. The objective is to obtain control over the anger, anxiety, guilt, and depression that constitute so much of even a psychologically healthy person's distress. Use of this technique would require the skills of a counselling psychologist and should not be attempted by a non-psychologist.

In the first place, it requires explanation and understanding that feelings are produced by the people who experience them and not by external circumstances. People experience inappropriately strong feelings because they hold irrational expectations about themselves ('I should always be perfect'), other people ('Others should always love me'), and the world in general ('The world should be arranged for my convenience'). When such irrational beliefs are frustrated, they lead to inappropriate negative feelings; on the other hand, abandoning them allows people to handle those inevitable upending experiences with greater composure.

In Roskies' procedure participants as a group silently first recall a situation in which (s)he was very upset, and then recreate as realistically as possible the feeling (s)he experienced at the time. Next, the person has to shift the feelings to a lower level, e.g. disappointment, frustration or irritation instead of outright anger and fury. Once (s)he has adjusted the feelings, the person is asked to recall her/his 'internal debate', i.e. what (s)he said to her/himself to change the irrational thinking and thereby the inappropriate feelings. After some practice, groups of two or three share their experiences. Homework consists of three short practice sessions a day during which the individual goes through the above sequence of rational-emotive thinking, then records the selfstatements. Back in the group, discussion of homework, assignments and other applications allow members and the group leader to suggest more rational self-statements.

The use of imagery to modulate feelings gradually changes to modification of feelings on the spot, thus shortening the duration of inappropriate feelings, and eventually after some weeks' practice even short-circuiting such disruptive reactions altogether.

\section{Goal setting}

Lack of direction is often a component of distress and some training in personal goal setting should be part of a stress management programme. Often the participants have skill and experience of goal setting as part of their occupational repertoire, but have seldom applied these to their own lives. 
Sessions on goal setting should be preceded by group discussions and other assignments aimed at helping the individual to clarify personal values. A thought-provoking article or two (Shepard, 1983) could set the ball rolling. If the person is married, the spouse should one way or another be involved in such assessments. It may even be worth asking some ultimate questions, like: 'Is this worth dying for?' or 'Is this worth getting divorced for?' or 'Is this worth losing my son for?' (Strümpfer, 1983b).

Goals should be explicit, objective, and measurable but also realistic and attainable. A goal could, for instance, be no longer to go on a particular kind of trip, to particular places, and to delegate those responsibilities to such and such subordinates; or to spend every Saturday afternoon participating in a particular activity, or range of activities, chosen for eustress-inducing reasons; or to take genuine non-business vacations at set times. A later phase in this process is establishment of a hierarchy of goals, i.e. setting priorities.

Goal setting should, in part, be conducted in counselling and group situations, but should also become part of the individual's day-to-day life, so that the spouse, children, friends, superiors, and colleagues could become directly involved. As experience with management by objectives has indicated, the person should commit him/herself to a goal in collaboration with someone else, i.e. publicly rather than privately.

An article by Kolb and Boyatzis (1984) on 'Goal-setting and self-directed behavior change' may be worth reading in this context.

One of the activities that should flow from goal-setting exercises should be planning for a limited set of specific objectives for back-home applications of learnings during the course. If at all possible, there should also be some followup activity at a later stage to enhance compliance.

\section{Time management}

In combination with goal setting and as a logical outgrowth of it, time management training should be introduced. The proportion of time devoted to such training would depend on participants' needs. Time management is one of the processes that can be used, particularly by managers, to accomplish tasks in an efficient and effective way, thus reducing much of the overload that is a major distressor; in fact, the effectiveness may lead to eustress feelings.

Instead of entering into detail, I want to refer to articles by Alexander (1981), Ashkenas \& Schaffer (1982), and Schuler (1979), although much more has been written. Films may also be useful in this context and the Time Life Video programme, 'Time Management for Managers', is worth considering (available from Highgold International). The training skills involved here are more in the nature of management consulting than those of a psychologist.

\section{Various life-style interventions}

Counselling in connection with adult developmental stages (Strümpfer, 1984) and career development is not ordinarily viewed as part of stress management. Perhaps it is one of the sound personnel procedures I have mentioned earlier. Yet so much of distress-eustress is involved with personal and career development that I want to add it as one of the special contributions from counselling and industrial/organizational psychology. While time management is a short-term extension of goal setting, this kind of counselling would be a long-term extension. Hall (1976) and Schein (1978) are good starting points for an avid reader.
Preventive health management (which could include physical exercise) is another general area to be attended to. Even a brief workshop should include some assessment activities and some information on nutrition, preferably by a dietician. Smoking, alcoholism and addiction are also areas that deserve serious attention (Eiser, 1982). It may also make sense to encourage participants to visit their physicians for assessment of at least serum cholesterol and blood pressure, in view of the role of these two factors in coronary heart disease; it would even make sense to arrange that both can be done on company premises or as part of a stress management and health programme.

\section{Tying it together}

If a stress management programme is introduced in the form of a workshop, it could run over from half-a-day to a week. Matteson \& Ivancevich (1982b) briefly described the contents of a two-and-a-half-day workshop, which seems like a reasonable length of time, provided there will be a follow-up meeting, perhaps of another half-a-day. Murphy's (1984) review showed that, in general, programmes which have employed more contact hours have reported greater reductions in both physiological measures and self-reports of distress symptoms. Spreading out a programme over several days, or even half-days, over a period of time may have advantages over a continuous period; a sandwich programme allows far more immediate applications in the work and home situations. Roskies (1983) and Roskies \& Avard (1982) used a lengthy period of weekly meetings for a Type A behariour change programme, breaking up the learnings into small units on purpose to allow for more practice at home and at work in between. As with all training, it is a matter of finding a balance between the benefits of massed and distributed practice.

In general, multimodal programmes appear to be more effective than teaching single skills (Murphy, 1984). One reason is that participants in a multimodal programme gain experience of various techniques and have the opportunity to choose those which work best for them. Examples are the choice between progressive muscular relaxation and meditation, or the choice between relaxation and physical exercise as ways of dealing with tension.

\section{Employee counselling programmes}

Lastly, I want to mention employee counselling programmes as a way to handle distress. This kind of programme provides opportunities to assist people at all levels of organizations, but probably more at the non-executive level where other forms of intervention may be more difficult to deliver and less likely to gain acceptance. It also implies direct attack on real-life problems. For such reasons, they seem to be something that deserves greater attention in South Africa. It does not mean by-passing management, nor replacement of the personnel department's more traditional approaches. On the other hand, the danger of building another empire should also be prevented.

Companies in the U.S., Canada, and the U.K. have been introducing counselling facilities for a whole range of problems related to home and work, including even Alcoholics Anonymous groups on site (Cooper, 1984). Hall \& Fletcher (1984) have described what seems to be a model worth emulating, since it provides for a great variety of advice and counselling, without trying to be everything to all. They described Control Data's Employee Advisory Resource (EAR) programme in the U.K., which developed out of a similar programme in 
the U.S. The objective was 'to provide an accessible and confidential source of advice and counselling which can cope with any problem employees choose to bring up' (p. 30). The British service is provided by a small team with a diversity of skills but outside specialists in areas such as finance, consumer affairs, law and medicine are used when necessary. Employees can telephone (even anonymously) for advice or counselling but over half of these initial enquiries lead to subsequent personal meetings in the counsellor's offices (remote enough to retain client anonymity) or when they visit company sites.

'The types of problems referred have been extremely diverse. About 65 per cent of the caseload has been on personal problems such as legal issues, financial and housing problems, physical health, marital concerns, consumer problems, mental health, and family matters. Some 35 per cent of cases were work related: career issues, the application of policies and procedures, transfer/reorganisation, interpersonal problems, performance issues, benefit issues, termination/discipline, working conditions and retirement.' (Hall \& Fletcher, 1984: 31 - 32)

The article provides reassurance about 'managerial by-pass' in connection with work problems, as well as even unions using the programme as a sounding-board and counselling resource.

\section{Programme evaluation}

With a variety of interventions such as described above, costbenefit evaluation of stress management programmes is obviously a complicated and difficult matter. Yet such followup is just about essential. For the participants, various forms of feedback are necessary as reinforcement. But far more important is that training efforts should pay their way on the basis of indications of change in terms of relevant criteria (Matteson \& Ivancevich, 1982b); it will become increasingly important to provide indications of benefits measured against costs (Murphy, 1984).

An intermediate measure of success would be durability: The degree to which participants continue to use the skills they had been taught after termination of the programme.

In the longer term, outcomes can be measured by systematically collecting data from participants, for instance selfreports of anxiety levels, sleep-problems, muscle tension levels, and experiences of coping ability or effectiveness. Ratings by superiors could provide indications of change in performance or of symptom interference with work. Surveys of morale and job satisfaction may also provide information. Harder criteria could be production figures, scrap rates, turnover rates, absenteeism, tardiness, accidents, grievance rates, per unit labour costs, and measures which hardnosed personnel managers are used to consider. The problems of finding hard criteria in the case of executives are more formidable, though. Health-care costs may also be worth looking at.

Confounding by Hawthorne effects is a serious problem in demonstrating training effects. Murphy considered 'nonspecific factors inherent in all training strategies like sitting in a comfortable position, the intention to relax, a credible training strategy, and motivation due to self-selection' (1984: 9), to be responsible for some of the changes that have been reported. In addition, he mentioned workers' interest in stress management programmes and their positive attitudes which result from indications that the organization is concerned about them - 'this results in a desire among participants to make the programme successful' (p. 8).

\section{Conclusion}

In highly industrialized and affluent countries, like the U.S., the U.K., Germany, or Sweden, stress management is something of a 'cherry on top'. It is very important but something that can be left until more serious matters have been gotten out of the way. Not so in this country.

As a result of the shortage in high-level human resources, managers and professionals are under great pressure; they are promoted to positions where their American and European opposite numbers would arrive only after another five or more years' training and experience. Similarly the skills shortage is creating unique pressures for technicians and skilled workers. The racial situation is creating vast and unique distress for black, brown and white industrial employees. All of these are intensified and compounded by economic and political conditions that make life in South Africa an unusually distressful experience. The problems are also intense, extensive and complex enough not to leave any hope that there will be significant relief even in another generation.

For these reasons, stress management - at all of the levels mentioned in this article - is not a luxury in South Africa, or something 'nice' to do for humanistic reasons. It is a matter of physical, psychological and social survival. Since adults spend eight or more hours of every working day on the job (as well as varying amounts of time travelling to and from work, often a distressful experience), and since personnel managers and industrial/organizational psychologists are responsible for the people aspects of the work environment, stress management in all of its forms ought to be a more serious matter to us than to most of our colleagues in other countries.

\section{References}

Alexander, L.D. 1981. Effective time management techniques. Pers. J., vol. 60, 637-640.

Ashkenas, R.N. \& Schaffer, R.H. 1982. Managers can avoid wasting time. Harv. Bus. Rev., May - June, 98-104.

Benson, H. 1974. Your innate asset for combating stress. Harv. Bus. Rev., Sept. - Oct., 86-92.

Benson, H. \& Allen, R.L. 1980. How much stress is too much? Harv. Bus. Rev., Sept. - Oct, 89-92.

Bloom, A.H. 1984. The imperative of enlightened self-interest in South Africa. Paper presented to U.S. Business Council, Harvard Club, New York, 8 June.

Caplan, R.A., Cobb, S., French, J.R.P., Van Harrison, R. \& Pinneau, S.R. 1975. Job demands and worker health: Main effects and occupational differences (NIOSH Report No. $75-160$ ). Washington, D.C.: Department of Health, Education and Welfare.

Carrington, P., Collings, G.H., Benson, H., Robinson, H., Wood, L.W., Lehrer, P.M., Woolfolk, R.L. \& Cole, J.W. 1980. The use of meditation relaxation techniques for the management of stress in a working population. J. Occup. Med., vol. 22, $221-231$.

Cooper, C. 1984. What's new in ... stress. Pers. Mgmt., June, 40-43.

Cooper, C. \& Arbose, J. 1984. Executive stress goes global. Int. Mgmt., May, 28-32.

Cooper C.L. 1980. Work stress in white and blue-collar jobs. Bull. Br. Psychol. Soc., vol. 33, 49-51.

Cooper, C.L. \& Marshall, J. (Eds.). 1980. White collar and professional stress. Chichester: Wiley.

Crown, S. \& Crisp, A.H. 1979. Manual of the Crown-Crisp Experiential Index. London: Hodder \& Stoughton.

Crump, J.H., Cooper, C.L. \& Maxwell, V.B. 1981. Stress among air-traffic controllers: Occupational sources of coronary heart-disease. J. Occup. Behav., 2, 293-303. 
Dayal, I. \& Thomas, J.M. 1968. Operation KPE: Developing a new organization. J. Appl. Behav. Sci., vol. 4, 473-506.

Eiser, J.R. (Ed.) 1982. Social psychology and behavioral medicine. Chichester: Wiley

Fordyce, J.K. \& Weil, R. 1979. Managing with people. 2nd Edition. Reading, Mass.: Addison-Wesley.

French, W.L. \& Bell, C.H. 1978. Organization development 2nd Edition. Englewood Cliffs, N.J.: Prentice Hall.

Greenberg, J.S. 1983. Comprehensive stress management. Dubuque, Iowa: Goodyear.

Hall, D.J. 1976. Careers in organizations. Pacific Palisades, Calif.: Goodyear.

Hall, J. \& Fletcher, B. 1984. Coping with personal problems at work. Pers. Mgmt., Feb., 30-33.

Henry, W.A. 1981. Take this job and love it. Time, 17 August, 35.

Howard, J.H. 1976. To reduce stress get yourself a senior manager's job. Can. Pers. \& Ind. Relat. J. January, $27-31$.

Ivancevich, J.M. \& Matteson, M.J. 1980. Stress and Work: A managerial perspective. Glenview, IIl.: Scott, Foresman.

Jenkins, C.D. 1984. Short Type A scale from the Activity Survey, Form N. Galveston, Texas: Author.

Jenkins, C.D., Zyzanski, S.J. \& Rosenman, R.H. 1979. Jenkins Activity Survey Manual. New York: Psychological Corporation.

Klausner, S.Z. (Ed.) 1968. Why man takes chances: Studies in stress-seeking. Garden City, N.Y.: Anchor.

Kolb, D.A. \& Boyatzis, R.E. 1984. Goal-setting and self-directed behavior change. In D.A. Kolb, I.M. Rubin \& J.M. McIntyre (Eds.), Organizational psychology: Readings in human behavior in organizations 4th Edition. Englewood Cliffs,: N.J.: Prentice-Hall.

Lynton, R. 1968. Comments on preceding article (Dayal \& Thomas, 1968). J. Appl. Behav. Sci., vol. 4, 507-509.

Maslach, C. \& Jackson, S.E. 1982. Burnout in health professions: A social psychological analysis. In G.S. Sanders \& J. Suls (Eds.), Social psychology of health and illness. Hillsdale, N.J.: Erlbaum.

Matteson, M.J. \& Ivancevich, J.M. 1982a. Managing job stress and health. New York: Free Press.

Matteson, M.J. \& Ivancevich, J.M. 1982b. The how, what and why of stress management training. Pers. J., vol. 61, $768-774$.

Meichenbaum, D. \& Jaremko, M.E. 1982 (Eds.). Stress reduction and prevention. New York: Plenum.

Moss, L. 1981. Management stress. Reading, Mass.: Addison-Wesley.

Murphy, L.R. 1984. Occupational stress management: A review and appraisal. J. Occup. Psychol., vol. 57, 1-15.

Peters, R.K. \& Benson, H. 1978. Time out from tension. Harv. Bus. Rev., Jan. - Feb., 120-124.

Poulton, E.C. 1978. Blue collar stressors. In C.L. Cooper \& R. Payne (Eds.), Stress at work. Chichester: Wiley.
Roskies, E. 1983. Stress management for Type A individuals. In D. Meichenbaum \& M.E. Jaremko (Eds.), Stress reduction and prevention. New York: Plenum.

Roskies, E. \& Avard, J. 1982. Teaching healthy managers to control their coronary-prone (Type A) behavior. In $\mathrm{K}$. Blankstein \& J. Polivy (Eds.), Self-control and selfmodification of emotional behaviors. New York: Plenum.

Schein, E.H., 1978. Career dynamics: Matching individual and organizational needs. Reading, Mass.: Addison-Wesley.

Schuler, R.S. 1979. Managing stress means managing time. Pers. J., vol. 58, $851-854$.

Shaffer, M. 1982. Life after stress. New York: Plenum.

Shamir, B. 1980. Between service and servility: Role conflict in subordinate service roles. Hum. Relat., vol. 33, 741-756.

Shepard, H.A. 1983. Life planning. In W.L. French, C.H. Bell \& R.A. Zawacki (Eds.), Organization development: Theory, practice and research (rev. ed.), Plano, Texas: Business Publications.

Sheppard, R.Z. 1981. The tape-recorder war. Time, 20 April.

Shostak, A.B. 1980. Blue-collar stress. Reading, Mass.: Addison-Wesley.

Simpson, J. 1983. The health enhancing organisation. Paper presented at conference on 'Wellness at Work: Psychological Aspects of Health Enhancement in Occupational Settings', Johannesburg, 2 August.

Strümpfer, D.J.W. 1975. Mense in rampe: Individuele en sosiale reaksies. Port Elizabeth: University of Port Elizabeth.

Strümpfer, D.J.W. 1983a. Coronary-prone behaviour and dystress among South African executives. Paper presented at Annual Congress, Psychological Association of South Africa, Pietermaritzburg, 16 September.

Strümpfer, D.J.W. 1983b. Executive dystress, executive eustress, and what makes the difference. Fact and Opinion Papers, no. 18 (Faculty of Business Administration, University of Witwatersrand).

Strümpfer, D.J.W. 1983c. Executive stress. In J. Barling (ed.), Behaviour in organizations: South African perspectives. Johannesburg: McGraw-Hill.

Strümpfer, D.J.W. 1984. Midcareer transition: Opportunities in work clothes. S. Afr. J. Bus. Mgmt, vol. 25, 85-95.

The riots: Petrol and flames. 1984. Financ. Mail, vol. 9. no. $10,29$.

\section{Appendix 1 Films}

Managing stress. CRM/McGraw-Hill. (Colour, $34 \mathrm{~min}$. ) McGraw-Hill, Isando.

Stress. CTVC. (Colour, 50 min.) Available from CTVC Film Library, Watton Rd., Bushey, Herts. WD2 2JF, U.K.

Stress at work. Mental Health Film Council. (Colour, 24 min.) Available from Mental Health Film Council, 22 Harley Street, London WIN 2ED, U.K.

Stress personalities. Ciba-Geigy, Isando. 